\title{
The Kurdish Issue in June 2011 Elections: Continuity or Change in Turkey's Democratization?
}

\section{Nil S. Satana}

To cite this article: Nil S. Satana (2012) The Kurdish Issue in June 2011 Elections: Continuity or Change in Turkey's Democratization?, Turkish Studies, 13:2, 169-189, DOI: 10.1080/14683849.2012.686575

To link to this article: http://dx.doi.org/10.1080/14683849.2012.686575

册 Published online: 06 Jun 2012.

Submit your article to this journal $\pi$

Llll Article views: 695

Q View related articles $₫$

4 Citing articles: 3 View citing articles 


\title{
The Kurdish Issue in June 2011 Elections: Continuity or Change in Turkey's Democratization?
}

\author{
NIL S. SATANA \\ Department of International Relations, Bilkent University, Ankara 06800, Turkey
}

\begin{abstract}
This article analyzes the Kurdish issue in various aspects before the June 2011 elections. The main research questions include what constitutes the major grievances of the Kurds; how the ongoing conflict is framed as "Kurdish issue" versus a "terrorism problem" and how major political parties in Turkey approach the issue and its solution in their 2011 election manifestos and rallies. This article contributes the literature on the Kurdish issue in particular and Turkey's democratic consolidation in general by identifying the problems and political views of all relevant sides. Finally, based on both a historical and empirical analysis, the article reflects on the reasons why the Adalet ve Kalkınma Partisi and Barıs ve Demokrasi Partisi have become the major players in addressing the Kurdish issue after the 2011 election. The findings are relevant for Turkish democratic consolidation in particular and the democratization literature in general.
\end{abstract}

I dedicate this goal to the martyred sons of all the peoples of the Republic of Turkey. I don't want this kind of violence in my country.

\section{Arda Turan}

When Arda Turan, a renowned football player uttered these words after the Kazakhstan-Turkey soccer game on September 3, 2011, he did not know he was getting into a whole new ball game. The next day, Turan was figuratively questioned, put on trial and executed by most nationalist media outlets in the country while he was literally applauded, appreciated and sublimed by the Kurdish political party, Peace and Democracy Party (BDP, Barış ve Demokrasi Partisi), the Kurdish media and Turkish left. ${ }^{1}$ Before June 2011 general elections, international observers predicted that the circumstances were ripe for the solution of the Kurdish issue. ${ }^{2}$ However, before and after the elections, the Kurdistan Workers Party (PKK, Partiya Karkerên Kurdistan) terrorist attacks rose to their peak since the mid-1990s and led to the deaths of numerous civilians, including women and children. ${ }^{3}$ For example, the

Correspondence Address: Nil S. Satana, Department of International Relations, Bilkent University, Ankara 06800, Turkey. Email: nsatana@bilkent.edu.tr 
Çukurca attack of October 19, 2011, in which 26 soldiers lost their lives to multiple simultaneous attacks and 18 were injured, was one of the worst attacks since the 1990s. It raised all voices in the country, particularly those of Turkish ultra-nationalists. ${ }^{4}$ The polarization of the society peaked when some conservative nationalists went as far to argue that the Van earthquake of October 23, 2011 was a divine sign to everyone but foremost to the Kurds to stop fighting. ${ }^{5}$ In a highly polarized environment, it has become harder for the likes of Arda Turan to openly want peace when large numbers demand reprisal and retaliation in Turkey.

This article analyzes the Kurdish issue in various aspects before the June 2011 elections. The major questions that the article tackles are: what are the political, cultural and economic grievances of the Kurds, Turkey's largest unrecognized ethnic minority?; how/why is the ongoing conflict framed as the "Kurdish issue" versus a "terrorism problem"?; how do major political parties in Turkey approach the issue and its solution in their 2011 election manifestos and rallies?; and, finally, what are the major bones of contention (and consensus, if any)?

This article contributes to the literature on the Kurdish issue in particular and Turkey's democratic consolidation in general by identifying the problems and political views of all relevant sides, as a recent International Crisis Group report argues that "given the recent violence, returning to a positive dynamic requires a substantial strategic leap of imagination from both sides." While the report points to the PKK and the Turkish state as the two sides, the June 2011 elections show that the incumbent Justice and Development Party (AKP, Adalet ve Kalkınma Partisi) and the proKurdish BDP have become the most influential actors with respect to the Kurdish issue in Turkey. The 2011 elections also demonstrate that the Nationalist Action Party (MHP, Milliyetçi Hareket Partisi) and the Republican People's Party (CHP, Cumhuriyet Halk Partisi) are marginalized in Kurdish-populated areas.

In the past, PKK attacks were perceived mainly as a security problem that was exacerbated by the support, direct and indirect, of several countries such as Syria, Germany and Greece. ${ }^{7}$ However, the AKP government has gradually changed the state discourse since 2002 and with the initiation of its 2010 "National Unity and Brotherhood Project," declared that the terrorism problem of Turkey can be resolved through a democratic opening and a pluralist perspective to mitigate the grievances of all ethnic and religious minority groups, including Kurds. ${ }^{8}$ While the AKP's approach became inconsistent in time dooming the Project to failure, Turkish society has become highly polarized in the last few years. For example, Ersin Kalaycioğlu finds that in the September 12, 2010 referendum on proposed constitutional amendments, which the Kurdish nationalists boycotted, Turkish society was vastly divided in terms of partisanship, ideological splits, economic satisfaction and religiosity. ${ }^{9}$ In this highly polarized setting, the June 2011 elections demonstrate that the AKP and the BDP need to work within the political system to not only solve the Kurdish issue but also consolidate democracy in Turkey through drafting a democratic constitution for all segments of the society, including official and non-official minorities. ${ }^{10}$ The alternative is only further polarization, which would result in an ongoing struggle that would not only undermine Turkey's hopes for democratic 
consolidation, but also waste its resources much needed in reconstructing cities such as the earthquake-stricken Van.

This article is divided into five sections. First, it analyzes the roots of the Kurdish issue and notes that presentation of it as a "terrorism problem" versus "Kurdish issue" has become intertwined in a cycle of struggle. Next, it examines the state's response to the issue, including recent attempts to pursue political reforms to resolve the longsimmering conflict. A brief assessment of the Kurdish political movement since 1991 follows. Finally, the article presents a comprehensive analysis of how the Kurdish issue is tackled in the election manifestos and campaign speeches of the major political parties in the parliament. It concludes with a summary and implications for future policy.

\section{"Terrorism Problem" Versus "Kurdish Issue"}

The Ottoman Empire collapsed in the prime era of the nation-state. Accordingly, the new Turkish Republic was built with the principles of a centralized, modernized (Westernized) and unitary nation-state. Metin Heper argues that the new state's definition of citizenry was not based on religion or ethnicity but on "civic nationalism," in which self-association with the state is sufficient for citizenry. ${ }^{11}$ Nevertheless, while neither the Constitution nor statesmen defined the new state on ethnic identity, frequent references to "Turks" in state discourse blended with the denial of Kurdish identity over the years and engendered restrictive policies. According to Mesut Yeğen, "Turkish citizenship has, from the beginning of the Republic, oscillated between an ethnic and a political definition of the (Turkish) nation" resulting in Kurdish grievances. ${ }^{12}$

The revolutionary practices of secularization in addition to rapid modernization through centralization of production and taxation led to rebellions in the southeast of Turkey where the Kurdish population resided with Arabs, Turks, Alevis and Assyrians, and had been accustomed to a decentralized state system for centuries. These rebellions, however, failed to derail the Turkish state from its main goals. Paradoxically, one could argue that, starting from 1925, Kurdish "rebellions have aided in the formation of two fundamental precepts: political unity and secularism," 13 which have underlined the state's policies toward not only the Kurds but all ethnic and religious groups in the country. The Republic was built on the premise of one nation and did not include ethnicity in the definition of its nationhood. ${ }^{14}$

The 1937-38 Dersim campaign (the massacre as Prime Minister Tayyip Erdoğan acknowledged it in 2009) that took place in a mainly Kurdish Alevi city - renamed Tunceli in 1935-led to more resentment among tribal networks in the region against the Turkish state. ${ }^{15}$ According to Hamit Bozarslan, the resistance of the Kurds in mid1920s and 1930s was rather a rural opposition of tribes and religious orders not to the Turkish state per se but rather to the notion of a central state. The situation, Bozarslan argues, changed in the 1970-90 period as the rural movement urbanized due to an awakening among Kurdish nationalist intellectuals which was enhanced by the insurgency of the PKK. ${ }^{16}$ Thus, as the Kurdish movement developed from a rural 
opposition to an organized urban movement in the 1970s by the Socialist Party of Kurdistan (Partiya Sosyalist a Kurdistan), Turkish Worker's Party (Türkiye İsçi Partisi $)^{17}$ and later the PKK, the collective memory and culture of the Kurdish people internalized violent opposition as the only possible alternative to the limited political space available to the Kurds and other citizens of Turkey alike. ${ }^{18}$

In sum, in the new Republic, the Kurdish movement started with rural violence in the 1920s and survived the official state discourse that denied Kurdish ethnicity throughout the following several decades. While the nature of the Kurdish conflict has significantly transformed from early rebellions to the PKK terrorism, many would argue that the increasing resentment among the Kurds against the state was a consequence of both failed assimilation policies and limited opportunities for access to political and economic power. ${ }^{19}$ This may be a consequence of the overall under-developed nature of the democratic regime that was dominated by military tutelary, which limited political opportunities for not only the Kurds but also the ideological factions in the Turkish society.

Since 1980, junta believed that all violent ideological groups were eliminated in the coup, the Turkish state was quite unprepared for guerilla war prior to the PKK's first attack in 1984 on security patrol stations in the Siirt and Hakkari regions. ${ }^{20}$ The PKK started off as a Marxist-Leninist organization rather than a Kurdish nationalist movement and operated from safe havens in Syria, the Bekaa Valley in Lebanon and later in Northern Iraq. ${ }^{21}$ Furthermore, the Kurdish diaspora in Europe generously funded PKK operations. ${ }^{22}$ In 1985, the Turkish state established the village guard system based on hiring Kurdish villagers and arming them against the PKK. However, in 1986, the PKK started killing village guards and their families to prevent villagers from cooperating with the state.

In 1988 and 1989, the PKK attacked civil servants until the realization of how attacks on civilians jeopardized the organization's prestige internationally. ${ }^{23}$ In 1990, after 13 militants were killed in a cave near Nusaybin in Mardin province, the PKK called for serhildan, which means public uprising. One of those killed in the operation was the son of a prominent Kurdish nationalist family and public protests lasted for days. ${ }^{24}$ In those years, the PKK committed several "crimes against humanity" such as the Pinarcık massacre in 1987 in which 8 village guards, 16 children and 8 women were slaughtered in a raid on a village in Mardin province. ${ }^{25}$ The organization started using suicide terrorism in mid- $1990 \mathrm{~s}^{26}$ and continued its attacks especially after the arrest of its leader, Abdullah Öcalan who was captured in Kenya in 1999. After his imprisonment in Turkey, Öcalan shifted his strategy for almost 20 years and affirmed that the Kurdish armed struggle should combine political struggle and civil disobedience. Thus, the PKK declared a ceasefire and withdrew forces to Northern Iraq. ${ }^{27}$ Its attacks, however, resumed on September 1, 2003, and more recently reached a peak not seen since the 1990s.

As this background shows, the Kurdish issue and Turkey's terrorism problem have long been intertwined and adversely affected the country's democratization as well as its foreign relations. ${ }^{28}$ The Kurds rebelled in the new Republic as early as the 1920 s and the undermining of the Kurdish identity and political rights by the state has 
created a culture of resistance. This in turn led to the justification of terrorism by the PKK supporters in 1980s, which further alienated the state and the public from the Kurdish movement. The Turkish state refrained from referring to the issue as a "Kurdish issue" and instead officially argued that the issue was about "terrorism." Thus, until recently, the careful separation by state authorities of the Kurdish citizens' grievances from the PKK attacks and demands helped the state to get public support for using military measures to curb terrorism. ${ }^{29}$ While "in the early 1990s Süleyman Demirel as president, and Erdal İnönü as leader of the Social Democratic People's Party (SHP, Sosyal Demokrat Halkçı Parti), had spoken publicly of the 'Kurdish reality," the issue was still not framed as a Kurdish issue, which further exacerbated the problem. ${ }^{30}$ Kemal Kirişçi and Gareth Winrow found that the Turkish state's efforts to officially deny the Kurdish ethnicity backfired by contributing to the growth of Kurdish national consciousness. ${ }^{31}$ Moreover, the PKK's callous terrorist acts justified military operations to the Turkish public and contributed to the limitation of Kurdish rights. ${ }^{32}$ As a result, a cycle of violence transpired regardless of how one refers to the actual problem.

\section{State Responses to the Kurdish Issue}

Upon reviewing the background of the Kurdish issue and/or the terrorism problem, one question begs for an answer: what has been the state's response to PKK attacks? The answer is simple but telling: while the state denied both the Kurdish identity and cultural aspects of the problem, military tactics were employed for the most part since the issue was officially framed as a terrorism problem. Nevertheless, several other coping mechanisms have been employed to makethe PKK militants to lay down arms.

The denial of the ethnic dimension of grievances of the Kurds has been accompanied by state efforts to frame the issue as an economic one, manifested by relatively low levels of economic development in the southeast. Thus, one coping mechanism has become referring to the issue as a regional one ("the southeast issue") as opposed to an ethnic one ("the Kurdish issue"). Consequently, almost all governments since the 1990s have proposed financial packages to develop the economy in the southeast. However, with the ongoing PKK attacks targeting infrastructure projects such as the dams built in the region, none of the economic measures worked.

Another coping mechanism the Turkish state used was the adoption of the infamous Anti-Terror Law No. 3713 in April 1991. Under Article 8 of this Anti-Terror Law, many people were imprisoned on the grounds of promoting a separatist agenda and belonging to terrorist organizations such as the PKK, further weakened Turkish democracy. The anti-democratic nature of the 1982 Constitution drafted under the junta regime after the 1980 coup increased the grievances of both the Kurds and other fragments of the Turkish society. ${ }^{33}$

From 1985 to 2003, various Turkish governments adopted eight amnesty programs. After the July 29, 2003 Amnesty Program, the PKK declared that it would 
not yield to repentance laws and those who surrender to the state would be punished for treason. ${ }^{34}$ Many militants were thus deterred from turning themselves into the security forces. Clearly, amnesty programs proved futile since the PKK declared the end of the five-year one-sided ceasefire only one month after the adoption of the 2003 program. Thus, the 1990s were mostly characterized by successful military operations and failed amnesty programs while the after-effects of Turkey's European Union (EU) candidacy have characterized the 2000s.

Turkey's bid for EU membership has left its mark on the Kurdish issue in the last decade. After declaring Turkey a candidate country in December 1999, the EU demanded changes to several undemocratic laws and codes. These reforms were passed between 2002 and 2004 through a series of eight reform packages. The Democratic Left Party (Demokratik Sol Parti) and MHP prepared the first three reform packages with the help of the Motherland Party (ANAP, Anavatan Partisi). The AKP established a majority government in 2002 and enacted the packages, which benefited the Kurdish population in various ways, in addition to other democratization benefits in general such as the transformation of civil-military relations. ${ }^{35}$ Freedom of speech and association caught up legally with Western democratic standards, albeit not in practice, especially once Article 8 of the Anti-Terror Law was repealed in 2001. The death penalty was also abolished, resulting in a much debated life sentence for Abdullah Öcalan. Moreover, radio and television broadcasting and language courses in Kurdish were legalized, ${ }^{36}$ ending a long ban on uses of the Kurdish language. ${ }^{37}$

These are very important developments since the lack of or the limited recognition of demands such as language and cultural rights has often been associated with minority violence in Turkey. ${ }^{38}$ The Kurds thus welcomed the EU harmonization laws requiring civilianization of Turkish politics, while Prime Minister Erdoğan officially acknowledged the "Kurdish issue" in 2005 in a historic speech in Diyarbakır.

\section{Kurdish Political Participation Since the 1990s}

Since inception of the Republic, the Kurds have participated in non-ethnic, mainstream political parties and took part in governing coalitions as ministers from mainstream parties. ${ }^{39}$ However, a Kurdish political party first participated in the parliament in only 1991, but has never been part of a governing coalition. Almost every Kurdish party has, eventually, been banned for jeopardizing the territorial integrity of the state and unity of the nation. In other words, for decades, political survival of the Kurds in Turkey has been possible through non-ethnic parties, while they have been marginalized because of an unusually high electoral threshold (ten percent to gain seats in the National Assembly) and the practice of banning political parties that "pose a threat" to the regime. Turkey is clearly not the only country to ban parties; Nancy Rosenblum argues that other democratic states such as Israel, Spain and Belgium have become "defensive democracies" as they all ban ethnic and religious parties. ${ }^{40}$ In this environment, political space available to the Kurds has been limited to three options: mainstream parties, various legal and illegal Kurdish political 
parties and Islamist politics. A brief background on Kurdish political participation in Turkey's elections points to the dissatisfaction of the Kurds with their options.

The first Kurdish ethnic party, the People's Labor Party (HEP, Halkın Emek Partisi) was established in 1990. In October 1991, the HEP and the SHP established an election alliance, which received nearly 21 percent of the vote. The banning of the HEP resulted in the foundation of the Democratic Party (DEP, Demokrasi Partisi) in $1993{ }^{41}$ The DEP, which did not run in any elections, was followed in 1994 by the People's Democracy Party (HADEP, Halkın Demokrasi Partisi), which boycotted the municipal elections, leading to Islamist Welfare Party's sweeping success in the southeast region. In 1995 general elections, HADEP received just over four percent of the national vote and once again stayed outside the parliament. Most votes in the southeast were cast for the center-right and conservative parties such as ANAP and the Welfare Party instead of HADEP. Hamit Bozarslan explains this failure as a consequence of tribal loyalties and the ethnic divisions among the Kurds. $^{42}$

The municipal elections of 1999 brought 38 municipalities under the control of HADEP, which slightly increased its votes to 4.75 percent in the parliamentary elections but once again remained below the threshold. There was a closure trial against HADEP in 1999 but, having survived that, the party was banned in 2003 by the Constitutional Court on the grounds that it had ties to the PKK. HADEP's successor, Democratic People's Party (DEHAP, Demokratik Halk Partisi) increased its vote total to 6.14 percent in 2002, but still remained outside the parliament. DEHAP was the dominant party in 12 provinces in eastern and southeastern Anatolia, performing better than the nationally victorious AKP. ${ }^{43}$ This, however, once again resulted in a limitation of the political space for the Kurds because

In 1995 and 1999 the pro-Islamist Welfare Party (RP, Refah Partisi) and Virtue Party (FP, Fazilet Partisi) benefited from HADEP being left out of the parliament. In 2002 it was the AKP, which on average gained less than half of the electoral support that DEHAP obtained in east and southeastern provinces, that benefited from this representational threshold. ${ }^{44}$

Still, Kocher argues that in 2002, "the Kurdish mainstream remains politically conservative and unwilling to embrace the leftist agenda of Turkey's only Kurdish party." 45 In fact, DEHAP dissolved itself after a major setback in 2004 municipal elections.

The Democratic Society Party (DTP, Demokratik Toplum Partisi) was established in 2005 and, in July 2007 elections, decided to run as an independent list. It received 5.32 percent of the national vote, but did well in several provinces in the east and southeast, which translated to 22 seats in the parliament. Ali Çarkoğlu states that the 2007 election was a turning point for political participation of the Kurds in nationwide elections and added that the Kurdish movement marginalized thus far by the PKK finally decided to bypass the threshold requirement. ${ }^{46}$ However, while the DTP won over 20 parliamentary seats, the AKP “doubled its vote from around 26 
percent to 53 percent in the Kurdish southeast region surpassing the votes of the ethnic Kurdish DTP." ${ }^{47}$ Rabia Karakaya Polat argues that the granting of cultural and identity rights and freedoms as well as economic welfare to the Kurdish population in AKP's first term (2002-07) are the causes of this success. Cem Başlevent et al., on the other hand, argue that the Electorate Tendency Survey conducted in April 2002 points to an increase in the votes of religious and nationalist political parties in Turkey in the last decade. ${ }^{48}$ Thus, the Kurds may have continued their voting habits in 2007, albeit a clear increase in support led to the change of tactics of the Kurdish political movement.

The AKP and the DTP have competed against one another in the southeastern cities in the 2009 local elections and the DTP increased the number of municipalities under its control to 99. According to Ekrem Güzeldere, the AKP has long ignored the DTP-ruled municipalities and after these elections.

In the entire southeast region, the AKP is still the strongest party, but compared to the outstanding results there in the parliamentary elections in 2007, with 52 percent, the new 38.34 percent [for the AKP in 2009] total marks a significant drop. $^{49}$

Another explanation of why the AKP has been strong in Kurdish-populated areas may be that most Kurds were indifferent to the Kurdish nationalist discourse and due to their religiosity, they have preferred to vote for conservative parties such as the FP and the AKP. ${ }^{50}$ This line of argument contends that only democracy and Islam can keep Turkey integrated. ${ }^{51}$ However, there are counter-arguments on religion's value in solving the Kurdish issue. Skeptical of the unifying nature of Islam for the Kurds in Turkey, Zeki Sarıgil argues, "According to the AKP, the secular nature of the Republic is the main cause of the Kurdish problem in Turkey,"52 while Hakan Yavuz and Nihat Ali Özcan blame the AKP for polarizing the Turkish society with the party's ineffective discourse based on religion. ${ }^{53}$

In this frustrating political background for the Kurds, the 2011 elections witnessed an unprecedented success for the Labor, Democracy and Freedom Bloc (EDÖB, Emek, Demokrasi ve Özgürlük Bloğu), formed by the BDP and other small leftist parties' candidates. The EDÖB received 6.58 percent of the national vote while the AKP received nearly half of all votes. This time, the AKP received 37.37 percent of the votes cast in 12 provinces that harbor a significant Kurdish population while the EDÖB received 50.8 percent and the CHP received only 3.95 percent of the votes in these provinces. The EDÖB won a significant success overall by garnering 36 seats, the majority of whom are Kurdish MPs. While by and large the AKP was the winner of the election, the party may have lost votes in the southeast because of its exclusionary attitude regarding the DTP and later BDP before elections. ${ }^{54}$ Moreover, DTP's ban in 2009, the so-called (KCK, Koma Ciwaken Kürdistan, Kürdistan Komünler Birliği) operations in the region that led to arrests of hundreds of people for being a member of an umbrella organization affiliated to the PKK, the inability of the National Unity and Brotherhood Project of 2010, initiated by the government 
to deliver its promises, and finally Erdoğan's increasingly nationalist/conservative discourse on the Kurdish issue, all contributed to the decline of Kurdish votes for the AKP in the 2011 elections. ${ }^{55}$ The next section analyzes the discourses of major parties in the electoral campaign of 2011 to search for clues as to how major parties view the Kurdish issue and how the BDP has advanced its status in the political arena while the AKP experienced a major decline in Kurdish votes.

\section{Major Political Parties and the Kurdish Issue in 2011 Election Manifestos and Campaign Speeches}

\section{Justice and Development Party}

The AKP's election campaign from 2007 to 2011 changed substantially regarding the context of the Kurdish issue. The 2007 campaign specifically targeted the Kurdish population's votes by acknowledging foremost the presence of a Kurdish identity, while the 2010 democratic opening targeted mainly their rights through democratization of the country via a new constitution. However, the AKP's 2011 electoral campaign lost Kurdish support as it antagonized the undecided Kurds in the southeastern provinces by openly denying the presence of a "Kurdish issue." Instead, the AKP targeted and won nationalist votes in the region, sharing a great deal of the Kurdish votes with the BDP. In other words, in the 2011 elections, contrary to 2007 elections, the AKP's major strategy was to win MHP voters as opposed to Kurdish voters.

The AKP's 160-paged election manifesto was prepared in great detail and organized into main titles of advanced democracy, developed economy, viable environment and brand cities, strong society and leading country, respectively. ${ }^{56}$ In line with the AKP's constant emphasis on defining itself as a party of service to the people, the widest category that appears in the manifesto is the viable economy. The Kurdish issue, on the other hand, was included in the manifesto in a more limited way. The actions taken by the government to solve the Kurdish issue were summarized as the lifting of language bans, initiating a "democratic opening" in 2010 through the National Unity and Brotherhood Project, which targeted further democratization of the country, and changed the perception of the Kurdish issue from a security/terrorism problem to a democracy problem. ${ }^{57}$ More importantly, the manifesto pointed to assigning increasing roles to local administrations for local services, implicitly aiming at addressing Kurdish demands for democratic autonomy. ${ }^{58}$ In sum, the manifesto highlighted the significance of the Kurdish issue and the difficulty of solving it; however, the claim was that the AKP was most qualified to solve it with its experience of nine years in government. The manifesto overall is professional in style and instead of pointing to the failures of other parties, highlighted the performance and vision of the AKP in the past and looking forward to the year 2023, the 100-year anniversary of the Turkish Republic.

The AKP's election manifesto is quite different from its leader Tayyip Erdoğan's election rallies, both in style and content. There were several rallies in which the party leader Erdoğan mentioned Kurds, the BDP or the PKK in one way or another. While 
the ideal method would be to analyze the prime minister's speeches in all these rallies, due to constrains of space, the focus of this article is on three speeches in Bingöl, Tuzla and Diyarbakır rallies. ${ }^{59}$ A careful analysis of all the speeches shows that these three speeches are most representative of how the AKP and Erdoğan envision the Kurdish issue and its solution. ${ }^{60}$

Erdoğan's Bingöl speech of June 8, 2011, is loaded with references to religion and how BDP's independent candidates abuse Islam to get votes from Bingöl. ${ }^{61}$ In its beginning, the speech openly equates the BDP, the EDÖB's independent candidates and the terrorist organization PKK. More importantly, Erdoğan cites passages from Öcalan's published books to show how Öcalan is not a true believer; according to Erdoğan, Öcalan tries to deceive the Kurdish people by stating that God has never sided with the Kurds. Moreover, Erdoğan criticizes Öcalan for his delusions of being a pseudo-God after fighting against his faith and for his contempt of namaz, the daily Muslim prayer, by calling it "a form of theatre." Erdoğan also indicts the BDP for treating Öcalan as a prophet and using religion for political purposes. Moreover, Erdoğan asks his "religious Kurdish and Zaza brothers" to vote against the BDP since he accuses the party (again since equated with the PKK) of threatening AKP candidates in Hakkari and throwing Molotov cocktails and burning children's faces in imam hatip high school dormitories in Cizre and Diyarbakır in early June to curtail AKP's support in the region. Hence, Erdoğan concludes that the BDP could not be a truly democratic party that can work for the interests of the Kurds.

In this speech, Erdoğan uses an analogy on "how the PKK has became the CHP of the 1940s" and how both are "fascist, status quo and oppressive structures." With this, Erdoğan not only equates the main opposition party with a terrorist organization and the BDP but also portrays all as heretics. Only afterwards, Erdoğan highlights actions taken by his party to solve the Kurdish issue: lifting the state of emergency from the Kurdish-populated regions, establishing a state TV channel in Kurdish, using billboards for election campaigns in Kurdish and opening Kurdish language courses. A final point is the socioeconomic performance of the AKP in the region; Erdoğan points to how the region's economy got better during his party's reign. Interestingly, he says he "loves" the Kurds and Zazas just as much as Turks and other ethnicities living in Turkey and that is merely due to his religious beliefs: "Love the created for the sake of the Creator." For that love, Erdoğan posits, he ended the bans, constraints and assimilation policies that the CHP brought upon the Kurds.

As mentioned earlier, Erdoğan's goal before the June 2011 elections seemed to further lure Kurdish voters, which worked like a charm before the 2007 elections while also targeting MHP votes. His speech at the Tuzla campaign speech of June 11, 2011 (as well as several others before that) lends support to this argument. Erdoğan called the MHP - the main adversary to Kurdish demands for greater rights and freedoms_- "racist" and "skull nationalist" in many of his speeches. This rhetoric is not new at all. In his rallies before 2009 municipal elections, Erdoğan used the same line arguing that the real nationalist strengthens the country's economy instead of hiding behind a nationalist discourse. ${ }^{62}$ In the Tuzla rally, Erdoğan points to more than $60 \mathrm{AKP}$ deputies of Kurdish origin and to the four 
Kurdish ministers in his cabinet. He contends that his party is the only party that properly represents the Kurds--implying the BDP does not. Moreover, he emphasizes the motto of "one flag, one country, one nation, one state" positing that the Kurds do not want independence. This motto is deemed as the best solution to the Kurdish problem, which Erdoğan implies almost achieved after practices such as lifting of the state of emergency, Kurdish broadcasting, etc. The speech highlights the service-oriented mentality of the AKP in the west and southeast alike; service in this discourse is equated to civilization, which, according to Erdoğan, is what all citizens of Turkey deserve.

Finally, the Diyarbakır rally of June 1 once again connects the themes of religion, nationalism and service highlighting the unity of the Kurds and the rest of Turkey by pointing to the heroic deeds that the Turks and Kurds have undertaken together. A Kurdish conqueror, Selahaddin Eyyubi (1138-93) and his religiosity are highlighted to convince the audience that religion is more binding than nationalism of any sort, Kurdish or Turkish. Once again, the violent actions of the PKK are cursed and bound with the BDP to persuade the Kurds that the AKP is more able and willing to represent the Kurds than these two separatist organizations. Overall, Erdoğan's discourse is based on claims that the AKP is the true believer, the true nationalist and the true democrat, whose aim is to attract not only nationalist votes but also Islamist and Kurdish ones. The rallies are different from the election manifesto in the sense that the latter is more rational and focuses on performance as opposed to the former that trashes opponents and polarizes voters.

\section{Labor, Democracy and Freedom Bloc}

The most concise of the election manifestos among the four major political parties analyzed is EDÖB's. ${ }^{63}$ The manifesto's jargon is in general anti-capitalist, antiimperialist and socialist since the bloc's parties are aligned at the far to moderate left of the ideological spectrum. The manifesto introduction clarifies the target as the AKP and argues that the incumbent party has not done anything in the last nine years for improving the major issues of the country such as the Kurdish issue, a new and democratic constitution and unemployment. Moreover, the manifesto points to first Erdoğan's acknowledgement of the presence of the Kurdish issue in 2005 and later the change of his discourse in 2011 to "there is no Kurdish issue, but our Kurdish brothers have problems." The priority of the manifesto is on the Kurdish issue; however, women, health, environment, democratization and economy are also part of a socialist agenda and discourse.

The manifesto's main argument is that as long as repression, assimilation, denial and deadlock in Kurdish affairs continues to be the state policy, the issue will remain unsolved. More specifically, the manifesto promises that the bloc would work for ending the war of 30 years if all parties, including the AKP, set aside political and economic profits, finalize ongoing negotiations with İmralı (aka Öcalan) from the last three years, form a commission to scrutinize massacres, and change the electoral law to lower the election threshold. Moreover, the manifesto proposes 
changing the very centralized political system in the country to one with more democratic autonomy, featuring a decentralized system of administration consisting of 2025 autonomous regions that would connect local authorities and the people with the central government and redistribute the taxes collected by the latter. In this framework, while Turkish would remain as the official language in the administrative bodies, other languages could be used upon needs of the region (in addition to freedom of education in one's mother tongue). More importantly, the manifesto emphasizes that this proposal aims to do what the republic should have done for several decades, and that this model would bring peace and democracy to the country as opposed to disintegration and separation. Interestingly, contrary to the BDP's previous secular stance, religious freedom is highlighted and there is specific reference to the wearing of the headscarf in a supportive way. Finally, the manifesto is keen on women's rights and concrete steps for improving women's lives in Kurdishpopulated regions and all over Turkey.

In line with EDÖB's election manifesto, the BDP's rallies centered around similar themes of Kurdish struggle for recognition of political and cultural rights. There were, though, interesting twists throughout the campaign, which deserve further deliberation. After a careful examination of all speeches, the bloc's Van, Mersin and Diyarbakır rallies are analyzed here as representative of Kurdish politicians' election discourses. ${ }^{64}$

First, the discourses in the rallies from the more hawkish party members differed from those of moderates to a great extent. For example, during the April 17, 2011 rally in Van, Abdullah Öcalan's former lawyer and an MP candidate Aysel Tuğluk, argued that Öcalan should be released from prison and should rightfully serve as his people's leader. Tuğluk added that the fight the Kurds carry out would continue until independence. ${ }^{65}$ This speech added to Tuğluk's several other speeches and actions supporting the PKK. Another MP candidate of EDÖB, Filiz Koçali's speech at the Diyarbakır rally in June 4 called for better conditions for Öcalan, and, contradicting the party's own election manifesto, demanded "a two-region system with an autonomous Kurdistan."

On the other hand, the Chair of the BDP, Selahattin Demirtaş, in rallies like the one in Mersin in June 5, followed a less radical discourse, pointing mostly to the operations undertaken by the security forces that arrested hundreds of BDP members including mayors in KCK operations for supporting PKK's urban structures aiming to replace the Turkish state. ${ }^{66}$ Demirtaş argued that not even the 1980 junta arrested so many people for their opinions and that Erdoğan spoke differently to the Kurds and Turks. In sum, BDP rallies show that the inner factions in the party and the Kurdish movement reflect differently on the BDP discourse. This is hardly different than other parties. However, overall, it seems that BDP's association with the PKK hurts the Kurdish party more than the AKP's association with an Islamist core hurts the AKP. While the AKP's base has accepted a non-violent political strategy, albeit one that still disturbs many defenders of the secular Turkish Republic, the BDP's association with the PKK that has carried out acts such as suicide terrorism against civilians is unacceptable for mainstream Turkish political parties and the majority of the public. 
Second, the BDP seems to have changed tactics by adding conservative politicians such as Şerafettin Elçi to the election bloc and religious elements to its discourse in its manifesto and rallies. ${ }^{67}$ Moreover, a former Islamist National View member, Altan Tan used a sharp religious discourse in rallies, and argued that the AKP had done nothing for the religious Kurds and Turks during its long tenure, including the headscarf issue and a new constitution. Tan's remarks in a Silvan (Diyarbakir province) rally of April 24 on how Erdoğan could bring Shari'a or the EU into the picture to solve Turkey's issues were very controversial. ${ }^{68}$ Moreover, boycotts of Friday prayers at the mosques have been used as an act of civilian disobedience by the Kurdish party ${ }^{69}$ pointing to the incorporation of religious discourse and acts into Kurdish politics. In sum, these developments reflect major changes: the centurieslong tribal divisions in the Kurdish movement seem to have been left behind before the June 2011 elections while the secular Maoist movement of the 1980s and 1990s has transformed into a populist, nationalist movement that incorporates religion and conservatism into its rubric. The movement, in a way, has finally reconciled with the conservative and tribal culture of the region, which led to unprecedented electoral success for the Kurds.

\section{The Republican People's Party}

The CHP's 135-page election manifesto is rich and organized. ${ }^{70}$ Similar to the AKP, the party arranged its manifesto under different headings of liberal democracy, environment-friendly economy, social equality and solidarity, urbanization and welfare, and foreign policy based on peace, democracy and development. The Kurdish issue per se was not acknowledged in the manifesto and there is only limited mention of Kurds in the text: "the CHP will establish pluralist and liberal democracy to lift the obstacles of the Kurdish citizens' enjoying their identity."71 Other than this reference, the manifesto referred to the development and unemployment problems of the east and southeast under the AKP government and promised to bring democracy and peace to the region as well as completion of development projects such as the Southeastern Anatolia Project, a comprehensive regional development project. The emphasis was on the multi-ethnic structure of the population and the unity of the state. Nevertheless, the CHP made a very important promise related to the Kurdish issue: under the heading of local administrations, the party pledged to lift the AKP's reservation on the European Charter of Local Self-Government that Turkey accepted, which guarantees political, administrative and financial independence of local administrations by law. The promised practice targets all local governments in Turkey, hence it would be fair to argue that the CHP does not pledge much specifically to the Kurds in the party's election manifesto while the election rallies tell a completely different story.

Upon examination of all CHP election rallies, the Hakkari and Eskişehir speeches are selected as representative to portray CHP's outlook of the Kurdish issue. ${ }^{72}$ The Hakkari rally is an especially significant one since the media and both the MHP and the AKP have used this rally to associate the CHP with the BDP/PKK. The 
Eskişehir rally is particularly interesting since it shows how the CHP discourse in the west of the country differs in terms of topics tackled, the tone and the framing of the Kurdish issue from the discourse used in the east and southeast.

The May 23, 2011 rally of the CHP in Hakkari was very controversial. First, the rally was packed while the AKP's rally in the same city the day before was boycotted. Second, the leader of the CHP, Kemal Kılıçdaroğlu, visited the mayor of Hakkari, Fadıl Bedirhanoğlu of the BDP, who was accused by Erdoğan of forcing shopkeepers in the city to close down their businesses before his rally. Kılıçdaroğlu listened to the mayor's complaints about the KCK operations that peaked before the elections, allegedly since the government wanted to intimidate and repress the opposition. Later in his speech, Kılıçdaroğlu harshly criticized the AKP government for arresting mayors that came to office with people's votes and for keeping them in prison for months without a conviction. Kılıçdaroğlu highlighted that the CHP wanted freedom and democracy for everyone even at instances of significant differences of opinion. ${ }^{73}$ Third, Kıliçdaroğlu referred to the European Charter of Local Self-Government and promised to abide by universal rules when the CHP came to power. ${ }^{74} \mathrm{He}$ further argued that strong local administrations could more readily provide services to the people, and the era of mayoral visits to Ankara to beg for funding for basic services would finally come to an end. Finally, Kılıçdaroğlu criticized Erdoğan for saying "there is no Kurdish issue in Turkey." He argued that Erdoğan did not listen to the problems of the Kurdish people; instead, the AKP government listened to people's private calls by tapping phone lines. Kılıçdaroğlu then made an important point: he stated he was ready to solve any problem related to ethnic or religious identity. By stating that no one should be "othered" in the country and that he would solve the issue of education in one's mother tongue, K1liçdaroğlu changed the CHP's traditional discourse of the Republican Era. Moreover, he added that the village evacuations in the region would be compensated and rehabilitated if his party won the elections. Finally, Kılıçdaroğlu was critical of Erdoğan for promising new prisons to the people in the region. This was another sign, he argued, of the repressive policies of the AKP government.

Kılıçdaroğlu's Eskişehir rally of June 4, on the other hand, harbored quite a defensive discourse and tone since it took place in a non-Kurdish-populated city. Since he was harshly criticized by both the AKP and the MHP after his speeches in the southeastern cities that lauded strong local autonomy, Kılıçdaroğlu did not mention regional autonomy in this rally. Instead, he highlighted the concept of a "common flag" that Erdoğan had been using in his rallies. Kılıçdaroğlu blamed Erdoğan for owning the flag for himself and stressed that the flag belonged to all 73 million citizens in Turkey. Interestingly, he did not mention the Kurdish issue at all in his speech; while in another Eskişehir rally in July 2010, he had framed the issue as a "terrorism issue" that was not solved by the AKP government for so many years, as opposed to a "Kurdish issue." ${ }^{, 75}$ Overall, the CHP's approach to the Kurdish issue was at best limited in its election manifesto and rallies and rather inconsistent as a whole, which explains why the CHP was a non-option for Kurdish voters in the southeast in the June 2011 elections. $^{76}$ 


\section{Nationalist Action Party}

There is not as much to analyze in MHP's election manifesto in terms of the party's approach to the Kurdish issue. ${ }^{77}$ As it had in the past, the party openly rejected any ethnic or rival identity to Turkish national identity and promised to stand against constitutional amendments or a new constitution that may lead to

transformation of individual rights and freedoms into ethnic collective rights; building a multi-ethnic state that politically and legally accommodates different ethnic identities; creating artificial minorities by giving status to languages other than Turkish; changing the definition of national identity to "Turkeyness (Türkiyelilik);" democratic autonomy; [and] education in other languages. $^{78}$

In other words, the MHP openly declared that it was against any attempts to solve the Kurdish issue because it denied the presence of any such issue; instead, in MHP's discourse, global dominant powers have used ethnic and religious differences and separatist terrorism to realize their aims on Turkey. The issue, then, is a terrorism problem and this security threat should be tackled with a strong military. ${ }^{79}$

The MHP was quite consistent with its discourse and action in terms of the Kurdish issue in its election manifesto and election rallies. After a careful examination of all rallies, speeches in Istanbul, Diyarbakır and Gaziantep rallies are selected to sample MHP's approach to the issue. The rallies in the east and southeast of the MHP's leader, Devlet Bahçeli, were more limited compared to those of Erdoğan and Kılıçdaroğlu, and it seems that the party did not try very hard to attract Kurdish votes. Bahçeli often argued that other parties talk differently in the east and the west and therefore the MHP is the only trustworthy political party. ${ }^{80}$ Nevertheless, while Bahçeli's speeches in the west (i.e. Bursa and Istanbul) went as far to blame the AKP and PKK for trying to partition the country in a secret alliance, the ones in the southeast (i.e. Diyarbakır and Gaziantep) were rather implicit in these claims. The tone was milder and the dose and directness of the accusations to the PKK were significantly reduced. Moreover, the past statist discourses of economic development being the region's only problem was often highlighted. For example, in his Diyarbakır rally of June 6, Bahçeli asked whether the economic problems in the region would be solved if education in one's mother tongue becomes a constitutional right. He pointed to the historical, religious and cultural ties that bind the Turkish nation together and asked the public to vote for the MHP if they wanted development. ${ }^{81}$ Furthermore, in his Gaziantep rally in June 10, Bahçeli argued that the democratic opening process that the AKP initiated led to an increase in terrorism and politicized separatist movements that now demanded democratic autonomy, a bilingual state, etc., which would eventually lead to secession demands. Among all his speeches, the Diyarbakir rally seems to be less polarizing due to its mild tone and the stressing of brotherhood of all groups in Turkey; however, the minor vote share of the MHP in the region shows that Bahçeli did not convince the Kurds that their utmost problem is 
unemployment and that there is a terrorism problem in the region that can only be tackled using military retaliation.

\section{After-Election Political Crisis and the Rise in Terrorism}

After the June 2011 elections, the CHP and BDP boycotted the National Assembly since eight of their deputies were still in prison, albeit not yet convicted in the KCK and Ergenekon trials. ${ }^{82}$ Moreover, the BDP's Diyarbakır deputy convicted of supporting the PKK, Hatip Dicle, lost his seat, which was transferred to AKP's Oya Eronat, raising AKP's total seats to 327. These acts raised concerns about the AKP's authoritarian tendencies, although Prime Minister Erdoğan highlighted the value of consensus in all segments of the political spectrum in his balcony speech after his party raised its votes for the third time-a record in Turkish political history.

The BDP's and the CHP's boycott of the Turkish Great National Assembly created an unprecedented situation, with the largest opposition party remaining outside the parliament. President Abdullah Gül and Parliamentary Speaker Cemil Çiçek's mediation efforts resulted in CHP swearing on July 1, followed by the BDP on October 1. The most important item on the agenda of the parliament since then has been the drafting of a new constitution. The AKP aimed at changing the constitution long before the elections and needed 367 seats for altering the constitution on its own, or 330 seats to take the change to a referendum. Neither option was possible after the election, which meant that the new constitution would require a broad consensus. ${ }^{83}$ However, the terrorist attack on civilians in Ankara by an armed branch of the PKK on September 21 cast a shadow over the first attempts of constitution writing, after which the BDP joined the parliament and the 12-member parliamentary commission led by the speaker of the parliament Cemil Çiçek to draft the new constitution. BDP's deputies Sırrı Süreyya Önder, Altan Tan and Ayla Akat became members of the commission that first met on October 13, 2011. ${ }^{84}$ However, the Çukurca attacks of October 18 on a day that the commission met for constitutional consensus led to calls for retaliation by many, including President Gül, ${ }^{85}$ while the BDP leader Selahattin Demirtaş called on both the PKK and the Turkish military to stop the fighting and asked everyone to search for ways to build peace. ${ }^{86}$ How that would be possible is, of course, depends on whether one perceives the issue as a "Kurdish issue" or solely a "terrorism problem."

\section{Conclusion}

After the June 2011 election, it became clear that two major political parties in Turkey publicly supported the context of the Kurdish issue: the AKP and the BDP. ${ }^{87}$ However, the AKP does not recognize the BDP as a representative of the Kurdish population although the party fared well in the southeast. ${ }^{88}$ Erdoğan also argues that the PKK is not representative of the Kurds, and points to the massacres of the organization of innocent civilians. ${ }^{89}$ While the PKK is recognized internationally as a terrorist organization, the BDP is a legal political party that raised its vote 
share from 5.2 to 6.4 percent in the last national elections and received votes of more than 2.5 million citizens in Turkey. BDP deputies serve with the rest of the deputies in a consensus commission to draft a new constitution. In other words, there is no justification of Erdoğan's claim that the BDP does not represent the Kurds. Repeated failure to recognize Kurdish presence in Turkey's political arena has led to a cycle of violent riots, struggle for political and cultural rights through legal means followed by brutal terrorist tactics and more political struggle. Turkish politicians have long been victims of wishful thinking that the Kurdish issue would go away on its own.

The analysis here contends that the June 2011 elections showed once again that the MHP and CHP were not deemed credible actors in the Kurdish issue; the former was reluctant to accept the presence of the issue and the latter was reluctant to address the issue using a more comprehensive approach. The once revolutionary AKP policies, on the other hand, are no longer consistent in terms of the Kurdish issue as the party tries to juggle nationalist, conservative and Kurdish votes. Finally, the BDP, as a pro-Kurdish party, has become stronger after incorporating conservative and traditional elements in its election bloc. However, the party is destined to be alienated in the country as long as it does not distance itself from the generally reviled PKK. While it may take a while to make a clear break with the PKK, better control of the hardliners in the party may restructure the perceptions of the other parties of the BDP as a legitimate actor in the country's politics and result in recognition of major rights of the Kurds in the new constitution.

A parliament that works toward a national consensus on a new and free constitution may not completely obliterate the effects of the 1980 coup and its constitution; nevertheless, it may console some including the Kurds. In a 1995 article, Nur Bilge Criss argued,

The only nonmilitary solutions to this conflict seem to be nationwide reforms, one being in the form of efficient local administration, a change in the electoral system from a single-tier to a double-tier system, and the containment of terrorist attacks in order to be free to build up the region's infrastructure. ${ }^{90}$

It seems that, sadly, these solutions that were offered 17 years ago are still valid in Turkey today.

\section{Acknowledgements}

I thank Paul Kubicek, Nur Bilge Criss, Burak Bilgehan Özpek, Zeki Sarıgil and Lerna Yanık, for valuable comments and suggestions. They have immensely contributed to the quality of the paper. I am grateful to Anastassia Boitsova for assistance. Yet, all errors remain mine.

\section{Notes}

1. See the following for examples from the Turkish media: http://siyaset.milliyet.com.tr/bdpkongresinde-arda-turan-a-buyuk-alkis/siyaset/siyasetdetay/04.09.2011/1434506/default.htm; http:// 
www.beyazgazete.com/video/2011/09/05/arda-ya-sert-uyari-akilli-ol-arda.html; http://www.iha.com. tr/haber/detay.aspx?nid=191434\&cid=11; http://www.hurriyet.com.tr/spor/futbol/18666569.asp

2. Pelin Turgut, "Turkey's Election Offers a Last Chance to Integrate the Kurds," Time (June 10, 2011).

3. See for attacks before elections: "PKK Leader Threatens Turkey with "Great War"' May 6, 2011. Available at http://english.aljazeera.net/news/europe/2011/05/201156134841944951.html (accessed on August 7, 2011) and for after elections: "PKK Kills Pregnant Woman, 6 Year Old in Batman Terror Attack," Today's Zaman, September 27, 2011.

4. See for example: "Yıkılmadık, Üzgünüz" Habertürk, October 20, 2011; "Çukurca'da Hain Saldırı: 24 Şehit, 18 Yaralı" Hürriyet, October 20, 2011.

5. Abdurrahman Dilipak, "Deprem ve..." Yeni Akit, October 27, 2011.

6. "Turkey: Ending the PKK Insurgency" International Crisis Group Report No. 213, September 20, 2011.

7. Nur Bilge Criss and Yavuz Tura Cetiner, "Terrorism and the Issue of International Cooperation," The Journal of Conflict Studies, Vol. 20, No. 1 (2000). Available at http://journals.hil.unb.ca/index.php/ JCS/article/view/4337/4976.

8. "National Unity and Brotherhood Project (2010)", pp. 10-13. The pdf document's link is no longer in the official AKP website.

9. Ersin Kalaycığlu, "Kulturkampf in Turkey: The Constitutional Referendum of 12 September 2010," South European Society and Politics, Vol. 17, No. 1 (2012), pp. 1-22.

10. F. Stephen Larrabee and Gonul Tol, "Turkey's Kurdish Challenge," Survival, Vol. 53, No. 4 (2011), pp. $143-152$.

11. Metin Heper, The State and Kurds in Turkey: The Question of Assimilation (Houndsmill, Basingstoke, Hampshire, UK: Palgrave Macmillan, 2007), p. 89.

12. Mesut Yeğen, "Prospective-Turks' or 'Pseudo-Citizens': Kurds in Turkey," Middle East Journal, Vol. 63, No. 4 (2009), p. 597. For a detailed assessment on this, see Zeynep Gambetti and Joost Jongerden, "The Spatial (Re)Production of the Kurdish Issue: Multiple and Contradicting TrajectoriesIntroduction." Journal of Balkan and Near Eastern Studies, Vol. 13, No. 4 (2011), pp. 375-388.

13. Hakan Yavuz and Nihat Ali Özcan, "The Kurdish Question and Turkey's Justice and Development Party," Middle East Policy, Vol. 13, No. 1 (2006), p. 105. Rebellions do not start with the 1925 uprising; there are others such as Koçgiri riot in 1921.

14. There is an ongoing debate on whether the notion of "Turk" in the Constitution refers to Turkish ethnicity excluding other ethnic groups such as the Kurds.

15. Nicole Watts, "Relocating Dersim: Turkish State-Building and Kurdish Resistance, 1931-1938," New Perspectives on Turkey, Vol. 23, No. 1 (Fall 2000), pp. 5-30.

16. Hamit Bozarslan, "Why the Armed Struggle? Understanding the Violence in Kurdistan of Turkey." In F. Ibrahim and G. Gürbey (eds.), The Kurdish Conflict in Turkey (New York: St. Martin's, 2000), pp. $17-18$.

17. Aylin Güney, “The People’s Democracy Party,” Turkish Studies, Vol. 3, No. 1 (2002), p. 122.

18. Ibid.

19. Although the Kurds have been equal in terms of political and economic rights, the Kurdish-populated areas are under-developed compared to the rest of the country. Moreover, the Kurdish political party has had limited access to the parliament due to the ten percent election threshold and constant party bans. Çarkoğlu argues that even though citizens of Kurdish origin could freely engage in politics, public service, business and other walks of life, any assumption of a distinct ethnic identity in the public realm and demands for its official recognition were curtailed. For more on this, see Ali Çarkoğlu, "Ideology or Economic Pragmatism? Profiling Turkish Voters in 2007," Turkish Studies, Vol. 9, No. 2 (2008), p. 318.

20. In this part, I rely partially on my research notes for the IVEO Project at START Center, University of Maryland, June 2011.

21. Ibid., p. 37.

22. Andrew Mango, Turkey and the War on Terror: For Forty Years We Fought Alone (New York: Routledge, 2005), pp. 35-36.

23. Aliza Marcus, Blood and Belief: The PKK and the Kurdish Fight for Independence (New York: New York University Press, 2009), p. 163. 
24. Ibid., p. 193.

25. See Mehmet Ali Birand, Apo ve PKK (Istanbul: Milliyet, 1992). After the massacre Abdullah Öcalan is quoted to say "We kill and gain authority!" (in Turkish) "Öldürelim, otorite olalım!” See Hasan Cemal, "Öldürelim, otorite olalım!" Milliyet, March 19, 2000.

26. Doğu Ergil, "Suicide Terrorism in Turkey," Civil Wars, Vol. 3, No. 1 (2000), pp. 37-54.

27. Joost Jongerden and Ahmet Hamdi Akkaya, "Born from the Left: The Making of the PKK." In Marlies Casier and Joost Jongerden (eds.), Nationalisms and Politics in Turkey. Political Islam, Kemalism and the Kurdish Issue (NY: Routledge, 2011), pp.143-145.

28. Nil S. Şatana, "The Kurdish Question and Turkish-American Relations," (in Turkish) "Kürt Sorunu ve Türkiye-ABD İlişkileri," Demokrasi Platformu, Vol. 13, No. 4 (Winter 2008), pp. 89-105.

29. This official separation may have helped the Turkish society at large to perceive the Kurds as nonviolent and compartmentalize the issue by blaming not the Kurds but the PKK for the occasional newspieces on the martyrs in the southeast.

30. Güney (2002), p. 124.

31. Kemal Kirişci and Garreth M. Winrow, The Kurdish Question and Turkey: An Example of a Transstate Ethnic Conflict (London and Portland, OR: Frank Cass, 1997), pp. 112-113.

32. This includes operations to Northern Iraq, with and without consent of the Iraqi authorities.

33. Burak Bilgehan Özpek, "Constitution Making in Turkey After the 2011 Elections," Turkish Studies, Vol. 13, No. 2.

34. Marcus (2009), p. 163.

35. Nil S. Satana, "Transformation of the Turkish Military and the Path to Democracy," Armed Forces \& Society, Vol. 34, No. 3 (2008), pp. 357-388.

36. There was no reference to Kurdish in the amendment; however, the implicit target was the Kurdish language. The state established a state-sponsored Kurdish TV in 2008, which is much criticized by Kurdish nationalists as another attempt for assimilation. The Kurdish language courses, on the other hand, did not become popular in the region. The Kurdish politicians, as a result, demand education in Kurdish in schools.

37. Emir Hasanpur, Kürt Diliyle İlgili Devlet Politikalarl ve Dil Haklarl, trans. Cemil Gündoğan (Istanbul: Avesta Yayınları, 1997).

38. Nil S. Satana, Third Party Intervention in Civil Conflicts: Sorting Out the Effects of Domestic Factors, Ph.D. Dissertation (Buffalo, US: State University of New York (SUNY), 2006).

39. There are several examples such as Hikmet Çetin, a foreign minister of Turkey in 1995 and others.

40. Nancy L. Rosenblum, "Banning Parties: Religious and Ethnic Partisanship in Multicultural Democracies," Law \& Ethics of Human Rights, Vol. 1, No. 1 (2007), pp. 48-49.

41. Ibid., p. 85 .

42. Hamit Bozarslan, “Turkey's Elections and the Kurds," Middle East Report, No. 199. Turkey: Insolvent Ideologies, Fractured State (Apr. - Jun., 1996), pp. 16-19.

43. Ali Çarkoğlu, "The Rise of the New Generation Pro-Islamists in Turkey: The Justice and Development Party Phenomenon in the November 2002 Elections in Turkey," South European Society and Politics, Vol. 7, No. 3 (2002), pp. 123-156.

44. Ali Çarkoğlu, “Turkey's November 2002 Elections: A New Beginning?” Middle East Review of International Affairs, Vol. 6, No. 4 (2002), p. 34.

45. Matthew Kocher, "The Decline of PKK and the Viability of a One-State Solution in Turkey," International Journal on Multicultural Studies, Vol. 4, No. 1 (2002). Accessed at http://www.unesco. org/most/vl4n1kocher.pdf

46. Çarkoğlu (2008), p. 318. Available at http://www.setav.org/Ups/dosya/7317.pdf (accessed on February 28, 2012).

47. Rabia Karakaya Polat, "The AKP and the Kurdish Issue: What Went Wrong?" SETA Policy Brief, No. 14 (May 2008).

48. Cem Başlevent, Hasan Kirmanoğlu and Burhan Şenatalar, "Empirical Investigation of Party Preferences and Economic Voting in Turkey," European Journal of Political Research, Vol. 44, No. 4 (2005), pp. 547-566. 
49. Ekrem E. Güzeldere, "Turkey: Regional Elections and the Kurdish Question," Caucasian Review of International Affairs, Vol. 3, No. 3 (2009), p. 292.

50. Mustafa Akyol, Kürt Sorununu Yeniden Düşünmek. Yanlış Giden Neydi? Bundan Sonra Nereye?, 5th ed. (Istanbul: Doğan Yayıncılık, 2007).

51. Ibid., pp. 261-262.

52. Zeki Sarigil, "Curbing Kurdish ethno-nationalism in Turkey: An Empirical Assessment of Pro-Islamic and Socio-economic Approaches," Ethnic and Racial Studies, Vol. 33, No. 3 (March 2010), pp. 533-553.

53. Yavuz and Özcan (2006), p. 105.

54. Kumru Başer, "BDP Destekliler 36 Milletvekili Çıkardı,” BBC Türkçe, June 13, 2011. Available at http://www.bbc.co.uk/turkce/haberler/2011/06/110612_election_kurds.shtml (accessed on September 20, 2011).

55. I am grateful to Zeki Sarıil for pointing to these factors behind the decline of Kurdish votes for the AKP.

56. "Türkiye Hazır Hedef 2023. 12 Haziran 2011 Genel Seçimleri Beyannamesi." Available at http:// www.akparti.org.tr/beyanname2011.pdf (accessed on September 14, 2011).

57. The discussion of the Kurdish issue is limited to pp. 10-13 under the heading of democratization.

58. The discussion of local administrations relevant to the Kurdish issue is limited to pp. $25-26$ under the heading of "Governance Aiming at the Citizen and Outcome."

59. The AKP speeches are extracted from the party's official website. After careful examination of all speeches, these three rallies were selected for analysis. All speeches centered on similar issues; thus, it is fair to argue that selecting other speeches would not make much of a difference for the analysis.

60. A systematic content analysis for all major political parties would be the most appropriate method of analysis to examine the discourses of the parties on the Kurdish issue. However, since that is beyond the scope of this paper, I leave that for future scholarship.

61. The following analysis is based on the rally archive at the AKP official website. Available at http:// www.akparti.org.tr/site/haberler/rabbimin-affina-siginarak-soyluyorum/8392 (accessed on September 25, 2011).

62. "Erdoğan: MHP Kafatası Milliyetçisi,” Radikal, March 13, 2009.

63. The manifesto is only 11 pages and it was quite difficult to reach the document since BDP's official website is under construction for quite some time. The party uses a blog available at http://bdpblog. wordpress.com/, which includes a party program but not the manifesto or rally speeches. Thus, I reached EDÖB's manifesto from individual deputy websites such as İstanbul MP Sebahat Tuncel's personal website: http://sebahattuncel.org/secim-beyannamesi or Ertuğrul Kürkçü’s personal website: http://www.ertugrulkurkcu.org/duyurular/emek-demokrasi-ve-ozgurluk-bloku-secim-beyannamesi/

64. There is no official source for the BDP rallies similar to the other party websites; thus, I had to rely on newspaper articles to select the rallies that pointed to important trends in the campaign.

65. "BDP Van'da Seçim Çalışmasını Başlattı," April 17, 2011. Available at http://www.gazete5.com/ haber/bdp-van-da-secim-mitingi-yapti-17-nisan-2011-104564.htm (accessed on September 20, 2011).

66. http://www.ertugrulkurkcu.org/haberler/demirtasmersin-halki-secim-mitingi-degil-zafer-soleni-yapiyor/ (accessed on September 22, 2011).

67. Mesut Yeğen, “The 2011 Elections and the Kurdish Question?” Insight Turkey, Vol. 13, No. 4 (2011), p. 152.

68. "Başbakan'a Şeriat Çağrısı," Vatan, April 24, 2011.

69. Dorian Jones, “Turkey: Kurds Boycott Mosques for Language Rights," Eurasianet, June 11, 2011. Available at http://www.eurasianet.org/node/63639 (accessed on June 11, 2011).

70. “Özgürlügün ve Umudun Ülkesi. Herkesin Türkiye'si. CHP 2011 Seçim Bildirgesi” available at http:// www.chp.org.tr/wp-content/uploads/secim_bildirgesi-web.pdf (accessed on October 2, 2011).

71. Ibid., p. 17.

72. The CHP speeches are extracted from the party's official website. After examining all, these three rallies were selected for analysis. All speeches centered on similar issues; thus, it is fair to argue that selecting other speeches would not make much of a difference for the analysis. 
73. "Hakkari'de Kılıçdaroğlu İzdihamı," Milliyet, Mayis 23, 2011.

74. When later criticized by Erdoğan for "promising autonomy to the Kurds through the Charter" Kıllçdaroğlu pointed to the AKP party program and 2011 election manifesto for doing the same. See http://siyaset. milliyet.com.tr/-yerel-yonetimlere-ozerklik-vaadi-ak-parti-de-de-var/siyaset/siyasetdetay/27.05.2011/ 1395375/default.htm

75. "Kılıçdaroğlu'nun Eskişehir Mitingi," Haberx, July 16, 2010. Available at http://www.haberx.com/ kilicdaroglunun_eskisehir_mitingi(17,n,10397698,018).aspx (accessed on October 1, 2011).

76. The CHP was able to get a significant amount of votes from Alevis in Tunceli in the East.

77. "2023'e Doğru Yükselen Ülke Türkiye Sözleşmesi. Ses Ver Türkiye” available at http://www.mhp. org.tr/kitaplar/MHP_2011_SecimBeyannamesi.pdf (accessed on September 25, 2011).

78. Ibid., pp. 43-44.

79. Ibid., pp. 176-180.

80. "Bahçeli'nin Yeni Rotası Hakkari," Star, June 8, 2011. Available at http://www.stargazete.com/ politika/bahceli-nin-yeni-rotasi-hakkari-haber-357316.htm (accessed on September 25, 2011).

81. Available at the official MHP website: http://www.mhp.org.tr/gbk.php?content=3042\&cat=52 (accessed on September 25, 2011).

82. A large number of civilians and military officers are tried since 2008 for establishing a clandestine armed terrorist organization called Ergenekon and plotting a coup against the government.

83. See Burak Bilgehan Özpek's article in this volume for a more detailed assessment of the new constitution.

84. "Anayasa Hazırlık Komisyonu Perşembe Toplanıyor," CNNTurk, October 10, 2011. Available at http:// www.cnnturk.com/2011/turkiye/10/10/anayasa.hazirlik.komisyonu.persembe.toplaniyor/632639.0/index. html (accessed on September 30, 2011).

85. "Gül: İntikam Büyük ve Misliyle Olacak," Radikal, October 19, 2011.

86. "BDP'den Çukurca Açıklaması," Radikal, October 19, 2011.

87. Yeğen (2011), p. 152.

88. "PKK Görüşmeleri Gerekirse Başlar," Sabah, October 2, 2011.

89. "Görüşme Yine Başlayabilir" Hürriyet, October 2, 2011.

90. Nur Bilge Criss, "The Nature of PKK Terrorism in Turkey," Studies in Conflict \& Terrorism, Vol. 18, No. 1 (1995), p. 34. 